\title{
STUDENT PERCEPTIONS OF EDUCATIONAL GAMES IN HIGHER EDUCATION: AN EMPIRICAL STUDY
}

\author{
Roslina Ibrahim, Universiti Teknologi Malaysia, lina@ic.utm.my \\ Samsudin Wahab, Universiti Teknologi Mara, samsudin10@yahoo.com \\ Rasimah Che Mohd Yusoff, Universiti Teknologi Malaysia, rasimah@ic.utm.my \\ Khalili Khalil, INSTEDT Desaru, khalili@instedt.edu.my \\ Azizah Jaafar, Universiti Kebangsaan Malaysia, aj@ftsm.ukm.my
}

\begin{abstract}
Studies of educational games (EG) have attracted researchers' attention especially in the last few years due to its promising potential as well as the factor of preferences of younger generations. Studies have found that EG can enhanced teaching and learning process. However, its acceptance rate is rather slow because of some reasons. Understanding students' acceptance factors can help designers design specific applications for intended users. This study investigated the factors that might affect student acceptance of EG. Derived upon user acceptance theory, we proposed and tested several factors (performance expectancy, effort expectancy, social influence and attitude) towards student preferences to use EG. This study present the details of instruments used and result of analysis done using descriptive and regression analysis. Findings would be useful for EG designers and policy makers in understanding student perceptions toward EG, hence, provide some guidelines in design and implementation of EG.
\end{abstract}

Keywords: User Acceptance, Educational Games, User Adoption, Student Perceptions, TAM, UTAUT

\section{INTRODUCTION}

The prospect of computer games as a learning tool has been widely discussed in various literatures due to its engaging and fun characteristics, in contrast with straight forward teacher-centered way of education approach. It is seems as a promising teaching and learning tools for the $21^{\text {st }}$ century as reported by Federal of American Scientists (FAS) [1]. Contemporary students or so called "digital natives" are also found to be attached to computer games technology like never before [2]. Games are said to be able to teach $21^{\text {st }}$ century skills such as problem solving, critical thinking, team working and collaboration as suggested by Gee [3].

Educational games are found to be as an effective learning tool as stated in various literatures. Garris et al [4] have found that EGs are able to help student on various learning domains such as cognitive, affective as well as psychomotor skills [4]. Among the EG findings that is widely discussed is its ability to increase student motivation to learn [5], [6], [7], [8]. One of the most important factors in education is motivation to learn. Therefore, a highly motivating EG should be able to transform learning approach like never before. A study by Garzotto [9] revealed that multiplayer online games provide learning benefits on affective level as well as knowledge domain. Other studies also acknowledged the benefits of using games for learning such as [10], [11], [12] and [13]. According to these studies, game motivates learning, offer immediate feedback, support skills, and influences changes in behavior and attitudes. Even though much promise have been suggested, much user assessment and design features are still left to be explored due to (its) the infancy of the field [14].

Research in educational games are rather very new in Malaysia with most studies focusing on student interest of games and educational games [15], [16], [17] project- based development and one-off user testing as in [6], [5], [13], [18]. Other studies investigate the design frameworks for educational games [19], [20], [21] or in the middle of investigation about EG effectiveness [22], [23], [24] among school children. Even though new in Malaysia, the pattern of EG research growth is on the rise and Malaysia is catching up quite well. With respect to that matter, recognizing student's acceptance factors may help game designers to understand its target users in better ways and leverage on the information in helping them during the design process.

Although EG are able to be an effective learning tool and improve the quality of education, it is not yet readily adopted by schools [25]. Several barriers exist regarding the technology as well as students, teachers and 
Volume XII, No. 1, pp. 120-133, 2011

administration factors. Among the barriers for EG adoption as proposed by de-Freitas [26] are: i) access to correct hardware and PCs, ii) effective technical support or access to this support, iii) familiarity with games-based software, iv) community of practice within which to seek guidance and support, v) enough time to prepare effective game-based learning, vi) learners group who like to use this approach and vii) cost associated with this kind of application.

The review of literatures also found that there is a dearth of empirical evidence on EG acceptance [27] even though several studies have discussed the challenges of EG implementation [10], [28], [29]. Furthermore, local literatures of educational game studies are still very much lacking even though game's popularity among younger generations are quite obvious [16], [17]. Consequently this study proposed to empirically investigate the factors of EG acceptance by using theory which grounded in user acceptance of information systems.

Findings from the study can be used to enrich understanding of student preferences and opinions regarding EG used for learning. It is useful for instructional games designers to take the findings into account while designing and developing educational games. In addition, it will give some insight for policy makers in investment of such applications - even though more in-depth studies are required for that kind of decision making process.

This paper is organized as follows: the following section discusses the theoretical background of this study. It will be followed by our research model and hypotheses. Following that would be research methodology and results of analysis. The last section is the conclusions.

\section{THEORETICAL BACKGROUND}

\section{Technology Acceptance}

Technology acceptance theory is derived upon Theory of Reasoned Action (TRA), a social psychological theory that defines relationship between beliefs, attitudes, norms, intentions and behavior. It indicates that individual behavior in using technology is determined by one's intention to perform the behavior. This intention is influenced by several factors or determinants. TRA has been extended to predict user intention in several other fields, consequently produced several new theories.

In the field of information systems (IS), Technology Acceptance Model (TAM) by Davis [30] is among the most widely used model in IS. It has being extensively applied into many types of information system including job related applications, business, government, e-commerce, internet banking, e-learning, and other online applications. TAM postulated that usefulness and ease of use are the main factors to predict behavioral intention. TAM illustration is shown in figure 1.

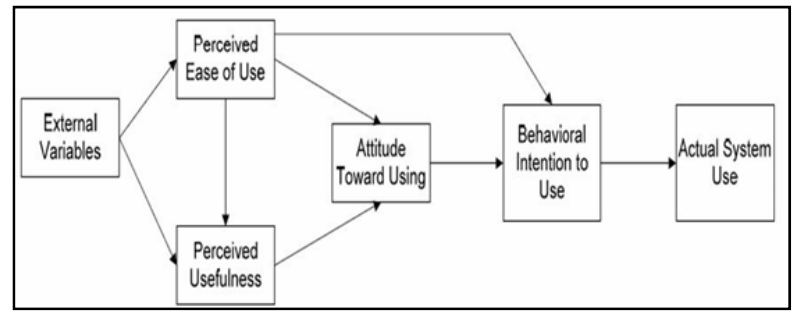

Figure 1: Technology Acceptance Model (TAM)

Upon the realization of multiple theories that co-exist in the field of IS concerning acceptance or adoption, Venkatesh et al [31] formulated and empirically validated 8 relevant theories into a unified theory called Unified Theory of Acceptance and Use of Technology (UTAUT). The 8 theories are i) Technology Acceptance Model (TAM), ii) Theory of Planned Behavior (TPB), iii) Theory of Reasoned Action (TRA), iv) Social Cognitive Theory (SCT), v) Model of PC Utilization (MPCU), vi) Diffusion of Innovation (DOI), vii) Combined TAM-TPB, and viii) Motivational Model (MM). 
Volume XII, No. 1, pp. 120-133, 2011

UTAUT have four direct determinants of user acceptance which are performance expectancy, effort expectancy, social influence and facilitating conditions, while two others are dependant variables; behavioral intention and use behavior. UTAUT also have four moderators (gender, age, experience and voluntariness of use) that moderate certain relationship between independent and dependant variables. Detail of the model is shown in figure 2.

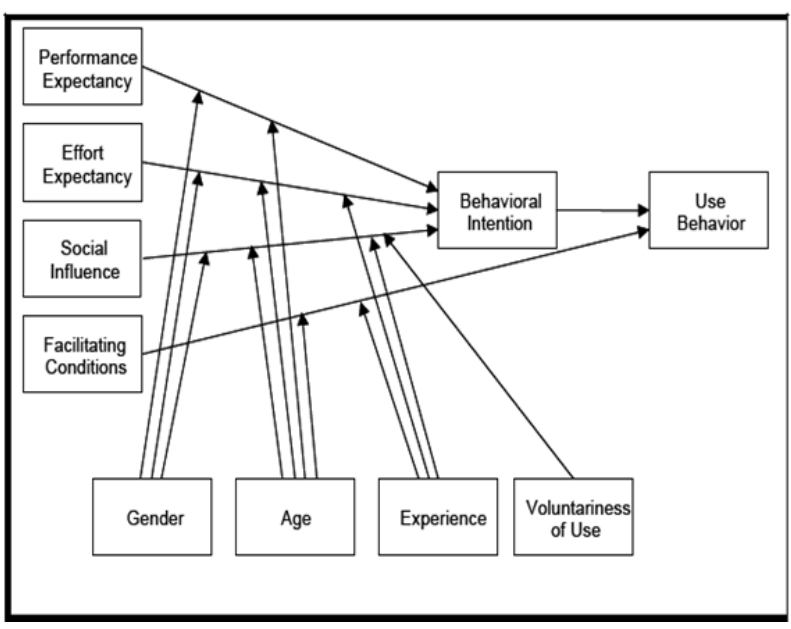

Figure 2: UTAUT Model

\section{Educational Game Acceptance}

Upon extensive reviews of literatures, it is found that there are still huge gap regarding acceptance studies of educational games. As to date, too little attention has being given on investigation on acceptance factors of EG. As the matter of fact, only a small number of studies have being implemented even on acceptance of common entertainment computer games. Considering the fact that both types of games have different nature and purposes, obviously different factors will influence its acceptance. Therefore, thorough investigation are needed to better leverage design and implementation of EG for educational purposes.

Several studies have identified acceptance factors of entertainment games. Hsu and Lu in [32] studied online gaming acceptance using extended TAM incorporated with social norm and flow experience. The model was able to explain about $80 \%$ of the variance. Ease of use was found as key determinants of online game. Ha et al [33] found that perceived enjoyment was better predictors than usefulness. Age was found as key moderator in acceptance of mobile broadband games.

In the case of educational games, Bourgonjon et al [27] found that student preference for educational games are affected by a number of factors, such as perceptions of student regarding usefulness, ease of use, learning opportunities and experience with video games in general. Gender effects are found as well, but mediated by experience and ease of use. Another study of EG acceptance among teachers using DOI theory did by Kebritchi in [25], found that teachers are ready to adopt EG provided that the games meet several requirements as describe below:

- Advantage: consists of the empirical indication of game effectiveness, game support features, gender-neutral features and engagement and problem-solving instruction strategies.

- Compatibility: consists of the game alignment with the state and national standards, available time for playing the game, available computers for playing the game and the teachers' technology training.

- Complexity: consists of a rich mathematical content, an attractive game context and story and the adjustment of the game difficulties.

- Trialability: consists of accessing to a trial version of the game. 
Volume XII, No. 1, pp. 120-133, 2011

Table 1 shows a summary of literature review in games acceptance studies. However, only two of the studies investigated the acceptance of educational game while the others are about entertainment games.

Table 1: Summary of games acceptance studies

\begin{tabular}{|c|c|c|}
\hline $\begin{array}{l}\text { Author, } \\
\text { Year, } \\
\text { Model }\end{array}$ & $\begin{array}{l}\text { Sample }(\mathrm{N}) / \\
\text { Technology/ system }\end{array}$ & Findings \\
\hline $\begin{array}{l}\text { Bourgonjon et al } \\
(2010) \\
\text { Extended TAM }\end{array}$ & $\begin{array}{l}858 \text { Flemish schools } \\
\text { students/ } \\
\text { Educational games/ } \\
\text { No system use }\end{array}$ & $\begin{array}{l}\text { Usefulness, ease of use, learning opportunities and personal } \\
\text { experience with games have direct effect on preference with } \\
\text { gender effect found to be mediated by experience and ease of } \\
\text { use. }\end{array}$ \\
\hline $\begin{array}{l}\text { Kebritchi, } \\
(2010), \\
\text { Diffusion of } \\
\text { innovation }\end{array}$ & $\begin{array}{l}3 \text { schools teachers/ } \\
\text { Educational games/ } \\
\text { Dimenxian }\end{array}$ & $\begin{array}{l}\text { Relative advantage, compatibility, complexity, trialability and } \\
\text { observability }\end{array}$ \\
\hline $\begin{array}{l}\text { Fang and Zhao } \\
\text { (2010) } \\
\text { Extended } \\
\text { TAM }\end{array}$ & $\begin{array}{l}173 \text { US university } \\
\text { students/ } \\
\text { Several games genre }\end{array}$ & $\begin{array}{l}\text { Enjoyment and perceived ease of use. Two personality traits } \\
\text { (sensation seeking and self-forgetfulness) have positive impact } \\
\text { on enjoyment }\end{array}$ \\
\hline $\begin{array}{l}\text { Fetscherin and } \\
\text { Lattemann } \\
\text { (2008) } \\
\text { Extended TAM }\end{array}$ & $\begin{array}{l}249 \text { second life users/ } \\
\text { Virtual worlds/ } \\
\text { Second Life }\end{array}$ & $\begin{array}{l}\text { Community, attitude, social norms have direct effect on } \\
\text { perceived usefulness while anxiety does not, ease of use effect } \\
\text { usefulness and intention. }\end{array}$ \\
\hline $\begin{array}{l}\text { Wang and Wang, } \\
(2008) \\
\text { Extended TAM }\end{array}$ & $\begin{array}{l}281 \text { responses/ } \\
\text { Online games/ World } \\
\text { of Warcraft, Lineage } \\
\text { and Maple Story }\end{array}$ & $\begin{array}{l}\text { Perceived playfulness on intention based on gender. Self- } \\
\text { efficacy, perceived playfulness and BI were all higher in men } \\
\text { while computer anxiety was higher in women. No gender } \\
\text { differences on system characteristics (speed, feedback and } \\
\text { challenge) }\end{array}$ \\
\hline $\begin{array}{l}\text { Ha, Yoon and Choi, } \\
\text { (2007), } \\
\text { Extended TAM }\end{array}$ & $\begin{array}{l}1169 \text { broadband } \\
\text { gamers/ } \\
\text { Mobile video games/ } \\
\text { Not stated }\end{array}$ & $\begin{array}{l}\text { Perceived enjoyment is better predictor than usefulness. Age } \\
\text { and gender are also key moderators of game acceptance. }\end{array}$ \\
\hline $\begin{array}{l}\text { Hsu and Lu, } \\
\text { (2004), } \\
\text { Extended TAM }\end{array}$ & $\begin{array}{l}223 \text { web based } \\
\text { gamers/ } \\
\text { Several Games on } \\
\text { different websites }\end{array}$ & $\begin{array}{l}\text { Social norm, attitude and flow experience explain about } 80 \% \\
\text { of game playing, key determinants is ease of use. }\end{array}$ \\
\hline
\end{tabular}

Due to lack of investigation in EG acceptance studies, we seek to further explore the perceptions of Malaysian undergraduate on using EG as one of their learning approach. In this study, we proposed to investigate the direct effects of student intention to use EG based upon revised Technology Acceptance Model (TAM) and Unified Theory of Acceptance and Used of Technology (UTAUT). We proposed the performance expectancy, learning opportunity, effort expectancy and attitude are the independent variables while student preference is the dependant variable.

\section{RESEARCH MODEL AND HYPOTHESES}

\section{Independent Variables: Performance Expectancy and Learning Opportunity}

Performance expectancy (PE) defined as "the extent to which an individual believes that using an information system (IS) will help him or her to attain benefits in job performance". PE is similarly used in TAM as usefulness. In this regard, games is used for educational reasons, therefore, the performance as mentioned here is specifically for learning purpose. However, Bourgonjon et al [27] argued that learning is more beyond performance only, it also heavily relies on its process. Learning opportunities (LO) considered the distinction between process and product of the two constructs. In this regard, PE is referred as the learning product while LO is the process. Perceived learning opportunities (LO) defined as "the extent which a person believes that using an online educational game can offer him or her opportunities for learning". Therefore, our hypotheses are: 
Volume XII, No. 1, pp. 120-133, 2011

H1: Performance expectancy positively affects preferences for online educational games.

H2: Learning opportunities positively affect preferences for online educational games.

\section{Independent Variable: Effort Expectancy}

Effort expectancy is defined as "the degree of ease associated with the use of system". This construct is similar with ease of use construct in TAM. It is considered the second most important factor in IS acceptance. Venkatesh et al (2003) formulated this construct from three previous models: TAM, MPCU and IDT. Therefore, we formulated the following hypothesis:

H3: Effort expectancy positively affects preferences for online educational games.

\section{Independent Variables: Attitude}

Attitude towards using technology is defined as "individual behavior overall affective reaction to using a system". Venkatesh et al (2003) explained that attitude was significant across many studies. Marchewka in [34] proposed that attitude will have direct effect on behavioral intention. Even though there are also studies that found attitude as not significant, we proposed to observe the variable with our students. Therefore, we proposed the hypothesis as follows:

H4: Attitude positively affects preferences for online educational game.

\section{Dependant Variable: Preference for Educational Games}

This study is in pre-implementation, whereby the actual use of the system is yet to be implemented. Therefore it is not possible to study the actual use of the educational games by the student. While both UTAUT and TAM have actually used it as a dependant variable, we decided to omit that in this particular stage. This is similar with Bourgonjon et al [27] argument that proposed to investigate only the respondent behavioral intention (BI). They further argued that behavioral intention can be a good predictor of actual use.

We use preference as the dependant variables as it seem to be more appropriate in pre-implementation stage of use as suggested by Bourgonjon et al [27].

\section{Research Model}

Based on our hypotheses, we proposed the model of student's perceptions of online educational games as in figure 3.

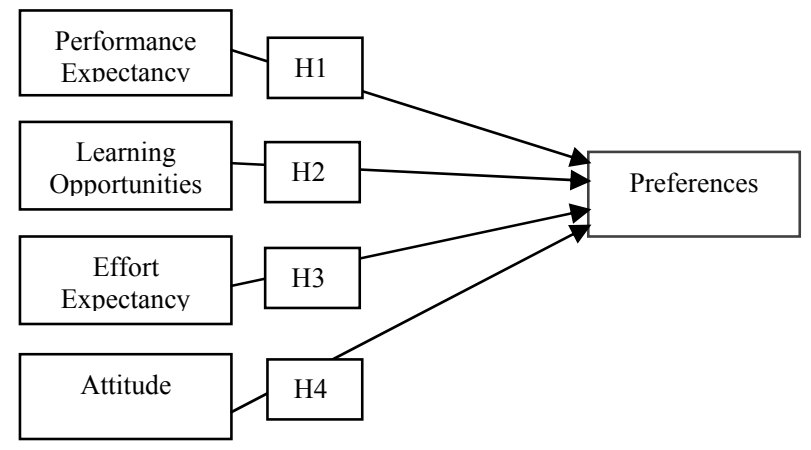

Figure 3: Proposed model for online educational games. 
Volume XII, No. 1, pp. 120-133, 2011

\section{METHODOLOGY}

\section{Instrument and Survey Process}

An online survey was developed based on original items developed by Bourgonjon et al [27] and Venkatesh et al [31]. The survey instrument has 21 questionnaire items with 5 constructs as in the proposed model. It uses 5 point Likert's Scale from 1 (strongly disagree) until 5 (strongly agree). Students were from IT background undertaking Diploma in Computer Science course at Universiti Teknologi Malaysia (UTM), Kuala Lumpur. 51 students completed the questionnaire $(\mathrm{N}=51)$ with male respondent of 29 students and female respondent of 22 students.

A reliability analysis was performed on overall items (as shown in table 2) as well as for every single construct (table 3) using Cronbach's Alpha. As shown, all constructs appear to have a good degree of reliability with the value of 0.75 and above.

Table 2: Reliability of all items

\begin{tabular}{|c|c|}
\hline Cronbach Alpha's & Number of Items \\
\hline .891 & 21 \\
\hline
\end{tabular}

Table 3: Reliability of each construct and number of items

\begin{tabular}{|l|c|c|}
\hline Constructs & $\begin{array}{c}\text { Cronbach } \\
\text { Alpha's }\end{array}$ & $\begin{array}{c}\text { Number } \\
\text { of Items }\end{array}$ \\
\hline Usefulness & .800 & 4 \\
\hline Ease of Use & .751 & 3 \\
\hline Learning Opportunity & .788 & 7 \\
\hline Attitude & .847 & 4 \\
\hline Preference & .839 & 3 \\
\hline
\end{tabular}

\section{Descriptive Analysis}

\section{RESULTS}

A descriptive analysis is provided in the following sections to provide richer understanding of the student's perceptions. Table 4 represents the results of descriptive analysis for performance expectancy (PE. In general, more than half of the students' belief EG can help them to perform better in their study; more than $70 \%$ stated that EG were able to improve their performances, increase learning productivity and enhance their effectiveness. The students also perceived EG can help them to achieve better grades (57\%), nevertheless about $37 \%$ students are not sure while $6 \%$ disagree about it.

Students perceptions on learning opportunity (LO) is also encouraging, results showed that students have a high tendency in believing that EG are able to provide opportunities towards their learning. Almost all of the students believe EG offer opportunities for them to experiments with knowledge (98\%). More than $85 \%$ of them also believe that EG are able to offer opportunities to experience things that they have learnt. The same tendency are also seen with other opportunities - control of learning process, transfer of various subjects, interaction with their friends and critical thinking, with more than $70 \%$ students agree and strongly agree. Even though about $30 \%$ of students are not sure EG can motivate them, more than $65 \%$ of them still believe EG able to provide motivation to learn. Detail result are shown in Table 5. 
Volume XII, No. 1, pp. 120-133, 2011

Table 4: Results for Performance Expectancy (PE)

\begin{tabular}{|c|c|c|c|c|c|c|}
\hline \multicolumn{2}{|c|}{ Items } & 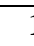 & 2 & 3 & 4 & 5 \\
\hline \multicolumn{7}{|c|}{ Using Online Educational games... } \\
\hline \multirow[t]{2}{*}{$\begin{array}{l}\text { PE1: Would improve my } \\
\text { performance }\end{array}$} & $(\mathrm{N})$ & 0 & 1 & 8 & 32 & 10 \\
\hline & $(\%)$ & 0. & 1.9 & 15.7 & 62.8 & 19.6 \\
\hline \multirow[t]{2}{*}{$\begin{array}{l}\text { PE2: Would increase my } \\
\text { learning productivity }\end{array}$} & $(\mathrm{N})$ & 0 & 3 & 7 & 30 & 11 \\
\hline & $(\%)$ & 0. & 5.9 & 13.7 & 58.8 & 21.6 \\
\hline \multirow[t]{2}{*}{$\begin{array}{l}\text { PE3: Would enhance my } \\
\text { effectiveness }\end{array}$} & $(\mathrm{N})$ & 0 & 3 & 9 & 28 & 11 \\
\hline & $(\%)$ & 0. & 5.9 & 17.6 & 54.9 & 21.6 \\
\hline \multirow[t]{2}{*}{$\begin{array}{l}\text { PE4: Would help me to } \\
\text { achieve better grades }\end{array}$} & (N) & 0 & 3 & 19 & 18 & 11 \\
\hline & $(\%)$ & 0. & 6.0 & 37.3 & 35.3 & 21.6 \\
\hline \multicolumn{7}{|c|}{ Result of mean, mode, median and standard deviations for performance expectancy (PE) } \\
\hline Items & Mean & & & Mode & \multicolumn{2}{|c|}{ Std. Dev } \\
\hline PE1 & 4.00 & & & 4 & \multicolumn{2}{|c|}{663} \\
\hline PE2 & 3.96 & & & 4 & \multicolumn{2}{|c|}{.774} \\
\hline PE3 & 3.92 & & & 4 & \multicolumn{2}{|c|}{.796} \\
\hline PE4 & 3.73 & & & 3 & \multicolumn{2}{|c|}{.874} \\
\hline
\end{tabular}

Table 7 provides descriptive analysis on the student's perceptions regarding attitude. Students tend to believe that use of EG would be a good idea (78\%) and fun (100\%). They also perceived that using EG can be more interesting for learning certain subject (95\%). An encouraging result on how student perceived to use EG that shows about $90 \%$ of the students believe that they will like learning with educational games.

Effort expectancy (EE) is another important aspect in acceptance of IS. It describes the level of ease of use associated with system usage. Encouraging results were also shown on this variables with most students believing that they have the skills and ability to operate the educational games (92\%). This is a good indicator that most students are actually familiar with game play activities and therefore have the skills to operate the applications for their learning purposes. They are also belief that it is easy to use EG and they can interact with games easily (more than $70 \%$ ). Table 6 shows the details of result for effort expectancy (EE).

Table 8 shows student preferences in using online educational games. An interesting result found in terms of student choice which indicate that almost $80 \%$ student choose to follow courses that use online EG if they have the choice of doing so. They also vote to use online EG in learning and are rather enthusiastic in using EG as one of their learning approach. 
Volume XII, No. 1, pp. 120-133, 2011

Table 5: Results for Learning Opportunities (LO)

\begin{tabular}{|c|c|c|c|c|c|c|c|}
\hline \multicolumn{3}{|c|}{ Items } & 1 & 2 & 3 & 4 & 5 \\
\hline \multicolumn{8}{|c|}{ Online educational computer games offer opportunities to... } \\
\hline \multirow{2}{*}{\multicolumn{2}{|c|}{ LO1: experiment with knowledge }} & (N) & 0 & 0 & 1 & 29 & 21 \\
\hline & & $(\%)$ & 0.0 & 0.0 & 1.9 & 56.8 & 41.2 \\
\hline \multirow{2}{*}{\multicolumn{2}{|c|}{$\begin{array}{l}\text { LO2: take control over the } \\
\text { learning process }\end{array}$}} & $(\mathrm{N})$ & 0 & 1 & 12 & 26 & 12 \\
\hline & & $(\%)$ & 0.0 & 2.0 & 23.5 & 51.0 & 23.5 \\
\hline \multirow{2}{*}{\multicolumn{2}{|c|}{$\begin{array}{l}\text { LO3: experi-ence things you learnt } \\
\text { about }\end{array}$}} & $(\mathrm{N})$ & 0 & 0 & 7 & 31 & 13 \\
\hline & & (\%) & 0.0 & 0.0 & 13.7 & 60.8 & 25.5 \\
\hline \multirow{2}{*}{\multicolumn{2}{|c|}{$\begin{array}{l}\text { LO4: stimulate transfer between } \\
\text { subjects }\end{array}$}} & $(\mathrm{N})$ & 0 & 1 & 12 & 23 & 15 \\
\hline & & $(\%)$ & 0.0 & 1.9 & 23.5 & 45.1 & 29.4 \\
\hline \multirow{2}{*}{\multicolumn{2}{|c|}{ LO5: interact with other students }} & $(\mathrm{N})$ & 0 & 2 & 7 & 24 & 18 \\
\hline & & $(\%)$ & 0.0 & 3.9 & 13.7 & 47.6 & 35.3 \\
\hline \multirow{2}{*}{\multicolumn{2}{|c|}{ LO6: think critically }} & (N) & 0 & 2 & 13 & 21 & 15 \\
\hline & & $(\%)$ & 0.0 & 3.9 & 25.5 & 41.2 & 29.4 \\
\hline \multirow{2}{*}{\multicolumn{2}{|c|}{ LO7: motivate students }} & $(\mathrm{N})$ & 0 & 2 & 15 & 22 & 12 \\
\hline & & $(\%)$ & 0.0 & 3.9 & 29.4 & 43.2 & 23.5 \\
\hline \multicolumn{8}{|c|}{ Result of mean, mode, median and standard deviations for Learning Opportunity (LO) } \\
\hline Items & Mean & & Median & & Mode & Std. Dev & \\
\hline LO1 & & 4.39 & & & 4 & & \\
\hline $\mathrm{LO} 2$ & & 3.96 & & & 4 & & \\
\hline $\mathrm{LO} 3$ & & 4.12 & & & 4 & & \\
\hline LO4 & & 4.02 & & & 4 & & \\
\hline LO5 & & 4.14 & & & 4 & & \\
\hline LO6 & & 3.96 & & & 4 & & \\
\hline LO7 & & 3.86 & & & 4 & & \\
\hline
\end{tabular}


Volume XII, No. 1, pp. 120-133, 2011

Table 6: Result of Effort Expectancy (EE)

\begin{tabular}{|c|c|c|c|c|c|c|c|}
\hline \multicolumn{3}{|c|}{ Items } & 1 & 2 & 3 & 4 & 5 \\
\hline \multirow{2}{*}{\multicolumn{2}{|c|}{$\begin{array}{l}\text { EE1: I would know how to handle } \\
\text { online computer educational games }\end{array}$}} & (N) & 0 & 0 & 4 & 34 & 13 \\
\hline & & (\%) & 0 & 0.0 & 7.8 & 66.7 & 25.5 \\
\hline \multirow{2}{*}{\multicolumn{2}{|c|}{$\begin{array}{l}\text { EE2: It would be easy to for me to use } \\
\text { online computer educational games }\end{array}$}} & $(\mathrm{N})$ & 0 & 1 & 10 & 23 & 17 \\
\hline & & (\%) & 0 & 1.9 & 19.6 & 45.1 & 33.3 \\
\hline \multirow{2}{*}{\multicolumn{2}{|c|}{$\begin{array}{l}\text { EE3: My interaction with online } \\
\text { computer educational games would be } \\
\text { clear and } \\
\text { understandable }\end{array}$}} & $(\mathrm{N})$ & 0 & 3 & 8 & 26 & 14 \\
\hline & & (\%) & 0 & 5.9 & 15.7 & 51.0 & 27.4 \\
\hline \multicolumn{8}{|c|}{ Result of mean, mode, median and standard deviations for Effort Expectancy (EE) } \\
\hline Items & Mean & & Media & & Mode & Std. D & \\
\hline EE1 & & 4.18 & & & 4 & & \\
\hline EE2 & & 4.10 & & & 4 & & \\
\hline EE3 & & 4.00 & & & 4 & & \\
\hline
\end{tabular}

Table 7: Result of Attitude (ATT)

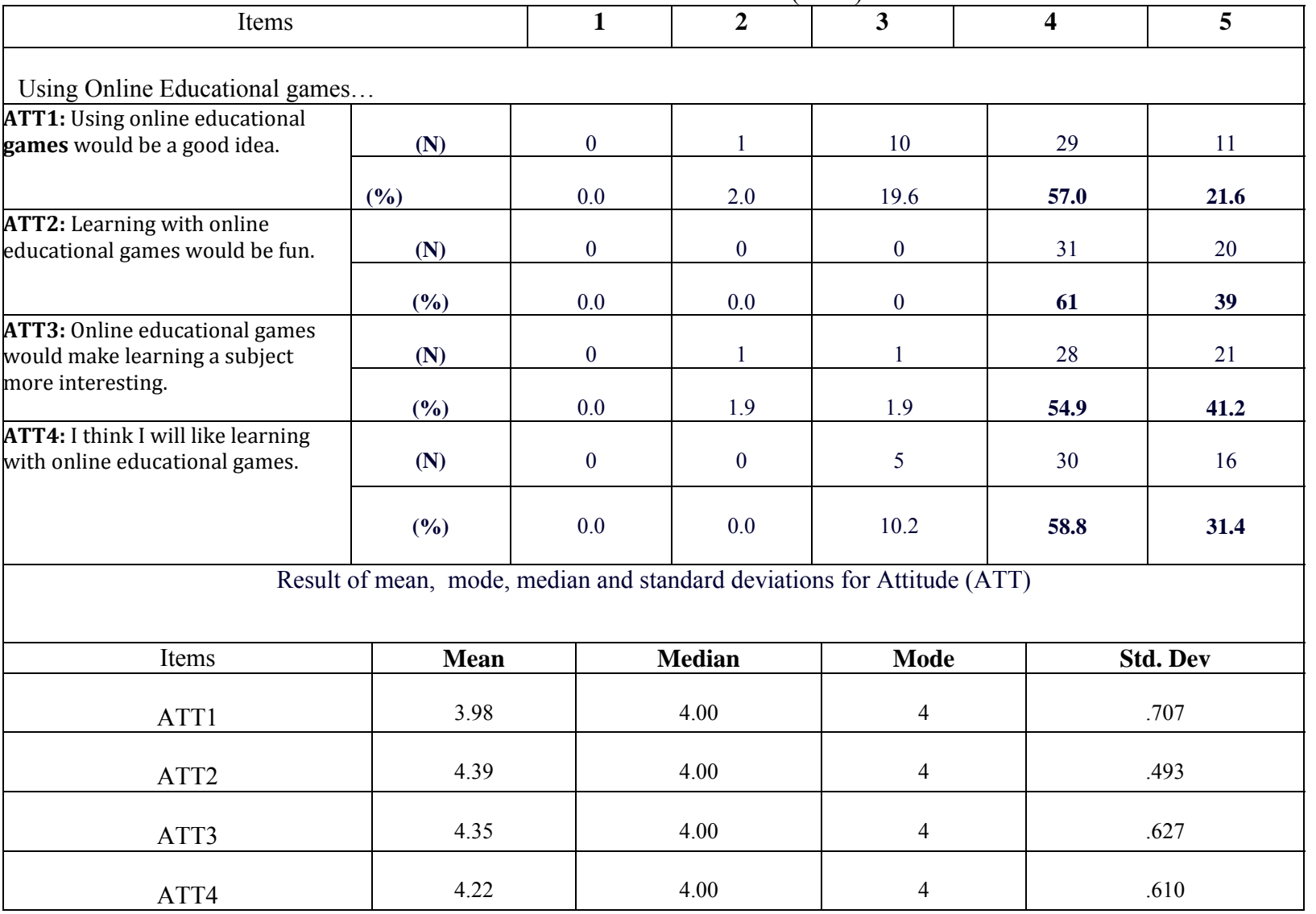


Volume XII, No. 1, pp. 120-133, 2011

Table 8: Result of student Preferences (PRF)

\begin{tabular}{|c|c|c|c|c|c|c|}
\hline \multicolumn{2}{|l|}{ Items } & 1 & 2 & 3 & 4 & 5 \\
\hline \multirow{2}{*}{$\begin{array}{l}\text { Prf1: If I had the choice, I would } \\
\text { choose to follow courses in which } \\
\text { online educational } \\
\text { computer games are used }\end{array}$} & $(\mathrm{N})$ & 0 & 5 & 7 & 29 & 10 \\
\hline & (\%) & 0.0 & 9.8 & 13.7 & 56.9 & 19.6 \\
\hline \multirow{2}{*}{$\begin{array}{l}\text { Prf2: If I had to vote, I would vote } \\
\text { in favor of using online educational } \\
\text { computer games } \\
\text { for learning }\end{array}$} & $(\mathrm{N})$ & 0 & 3 & 7 & 32 & 9 \\
\hline & $(\%)$ & 0.0 & 5.9 & 13.7 & 62.8 & $\mathbf{1 7 . 7}$ \\
\hline \multirow{2}{*}{$\begin{array}{l}\text { Prf3: I am enthusiastic about using } \\
\text { online educational computer } \\
\text { games as one of my } \\
\text { learning approach }\end{array}$} & $(\mathrm{N})$ & 0 & 3 & 9 & 26 & 13 \\
\hline & (\%) & 0.0 & 5.9 & 17.7 & 51 & 25.5 \\
\hline \multicolumn{7}{|c|}{ Result of mean, mode, median and standard deviations for Preferences (PRF) } \\
\hline Items & ean & Med & & Mode & Std. I & \\
\hline PRF1 & 3.86 & & & 4 & & \\
\hline PRF2 & 3.92 & & & 4 & & \\
\hline PRF3 & 3.96 & & & 4 & & \\
\hline
\end{tabular}

\section{Cross Tabulation Analysis}

In addition of the above studies, we also asked the students about their medium of game plays, duration of game play per week and reasons for playing games. Furthermore, we did the cross tabulation of those three activities based on gender. The results are as follows.

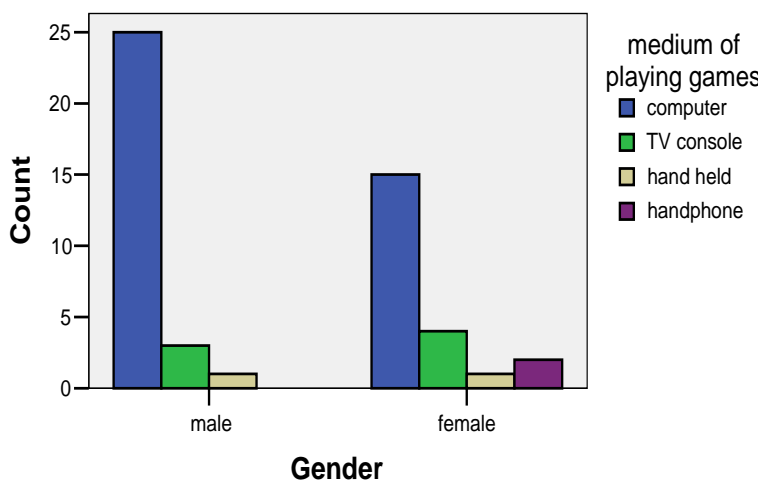

Figure 4: Medium of game play and cross tabulation between genders

Figure 4 shown the game playing medium preferred by students and its cross tabulation between gender. Obviously, the computer is the most preferred medium for playing games compared to console, hand held or hand phone. Both males and females also preferred computers followed by TV console, but male chooses handheld as their third choice while female chooses hand phone followed by handheld devices. It is surprising that the males do not really play games using hand phone even though most of them have access to hand phones.

Another activity is about duration of game play per week. Overall, 21 samples play game more than 5 hour per week, followed by 17 play between 1 to 5 hours and the rest play games 1 hour or less per week. However, it is quite interesting to observe the game play pattern between male and female. Generally, studies have found varied result of male and female playing pattern, some found that both gender have about the same pattern while others found that female play games less than male. 
Within our sample, we found that their playing duration per week is in opposite pattern. Almost all of male student play games more than 1 hour per week with more than half play more than five hours per week. On the other hand, most female play less than one hour per week followed by 1 to 5 hours and more than 5 hours. There are also small percentages of females that do not play games at all. This information is important when it comes to game development for educational purposes because it can affect female students' usage patterns. Thus, more knowledge is needed as to why females play games less[27]. Figure 5 shows the cross tabulation of play duration per week according to gender.

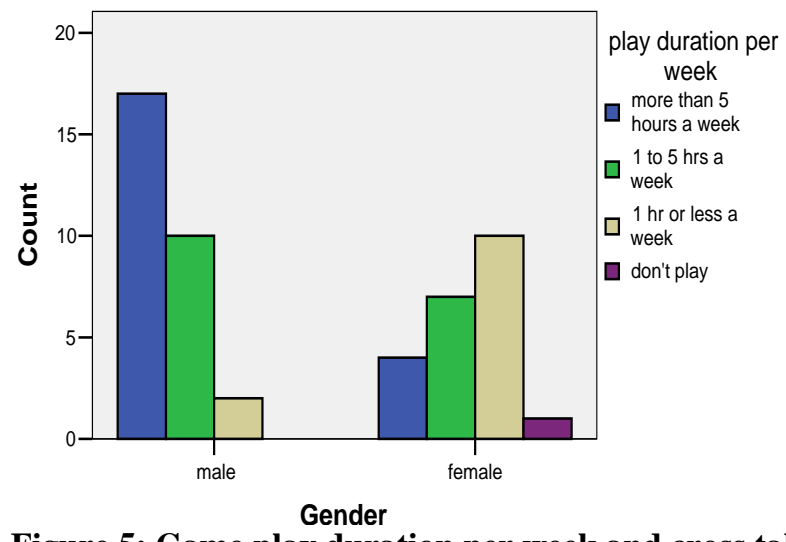

Figure 5: Game play duration per week and cross tabulation between genders

Figure 6 shows the cross tabulation of reasons for playing games between genders. Overall, student play games to fill up free time, followed by fun, challenging and lastly on graphic. However, playing patterns are quite different between male and female. Most male students play games to fill up free times while most female play it for fun. Male found challenge as one of the reason to play while female score very much less on challenge. Both male and female score the least on graphic as the reason for them to play games. Refer figure 6 for details.

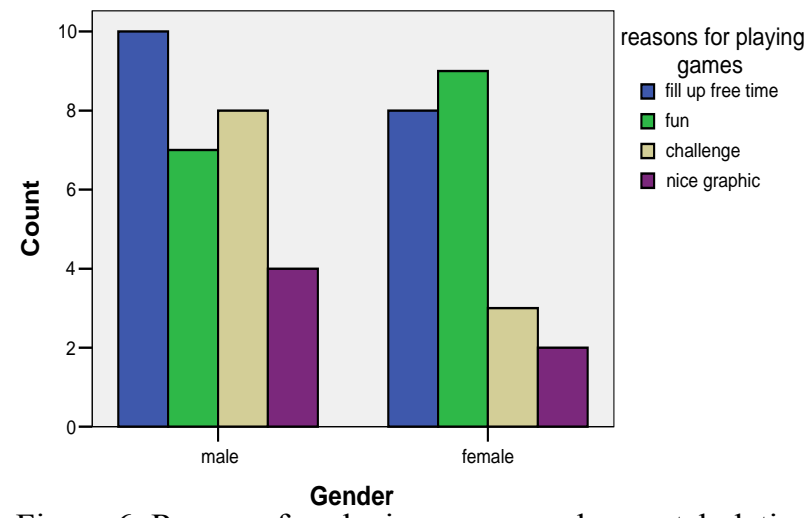

Figure 6: Reasons for playing games and cross tabulation between genders

\section{Correlation Analysis}

Analysis of correlations between variables shown that positive correlations exist between all of the variables with the strongest is between attitude and preferences. It is followed by effort expectancy with preference, learning opportunity and performance expectancy. Details of correlations analysis are shown in table 9 . 
Volume XII, No. 1, pp. 120-133, 2011

Table 9: Result for Correlation Analysis (Pearson Correlations)

\begin{tabular}{|c|c|c|c|c|c|}
\hline & $\mathrm{PE}$ & EE & LO & ATT & PREF \\
\hline $\mathrm{PE}$ & 1 & & & & \\
\hline $\begin{array}{c}\text { EE } \\
\text { Sig. }\end{array}$ & $\begin{array}{r}.387^{* *} \\
.005\end{array}$ & 1 & & & \\
\hline $\begin{array}{l}\text { LO } \\
\text { Sig. }\end{array}$ & $\begin{array}{c}.539^{* *} \\
.000\end{array}$ & $\begin{array}{c}.425^{* *} \\
.002\end{array}$ & 1 & & \\
\hline $\begin{array}{l}\text { ATT } \\
\text { Sig. }\end{array}$ & $\begin{array}{c}.330^{*} \\
.018\end{array}$ & $\begin{array}{r}.455^{* *} \\
.001\end{array}$ & $\begin{array}{c}.652^{* *} \\
.000\end{array}$ & 1 & \\
\hline $\begin{array}{l}\text { PRF } \\
\text { Sig. }\end{array}$ & $\begin{array}{r}.462^{* *} \\
.001\end{array}$ & $\begin{array}{c}.645^{* *} \\
.000\end{array}$ & $\begin{array}{c}.546^{* *} \\
.000\end{array}$ & $\begin{array}{c}.692^{* *} \\
.000\end{array}$ & \\
\hline
\end{tabular}

\section{Regression Analysis}

There are significant positive relationship between effort expectancy and preferences $(\beta=.368, \mathrm{p}=0.001)$. Also, there are significant positive relationship between attitude and preferences $(\beta=.477, p=000)$. Therefore, hypotheses 3 and 4 are accepted. This finding is similar to Bourgonjon et al [27] and Marchewka [34].

However, there are no significant positive relationships found between performance expectancy and preferences, and between learning opportunities and preferences ( $\mathrm{H} 1$ and $\mathrm{H} 2)$. This finding contradicts with most user acceptance studies, however other studies exposed the IS to the user before distribution of questionnaires. In our case, EG is considered vey new and most student have not played any games for learning. Therefore, it is probably rather difficult for them to see how the process and effect of EG without trying the real EG. Therefore, these constructs are better to be used after real exposure to IS that involve any user acceptance study. Result of regression analysis is shown in figure 7.

\begin{tabular}{|c|c|c|c|c|c|c|}
\hline \multicolumn{7}{|c|}{ Coefficients $^{\mathrm{a}}$} \\
\hline \multirow{2}{*}{\multicolumn{2}{|c|}{ Model }} & \multicolumn{2}{|c|}{ Unstandardized } & \multirow{2}{*}{$\frac{\text { Standardized }}{\text { Beta }}$} & \multirow[t]{2}{*}{$\mathrm{t}$} & \multirow[t]{2}{*}{ Sig. } \\
\hline & & $\bar{B}$ & $\begin{array}{l}\text { Std. } \\
\text { Err. }\end{array}$ & & & \\
\hline \multirow[t]{5}{*}{1} & Const & -1.323 & .606 & & -2.182 & .034 \\
\hline & $\overline{\mathrm{PE}}$ & .192 & .123 & .168 & 1.558 & .126 \\
\hline & $\overline{\mathrm{EE}}$ & .433 & .122 & .368 & 3.539 & .001 \\
\hline & LO & -.018 & .187 & -.013 & -.095 & .924 \\
\hline & ATT & .659 & .168 & .477 & 3.929 & .000 \\
\hline
\end{tabular}

Figure 7: Regression Analysis

\section{CONCLUSIONS}

This study investigated students' perceptions towards usage of online educational games for their learning. This pre-implementation study was done to assess students' beliefs in using educational games for learning by using modified items from Technology acceptance Model (TAM) and Unified Theory of Acceptance and Use of Technology (UTAUT). Samples are from a university in Kuala Lumpur, undertaking diploma course in information technology. We proposed four independent variables and one dependant variable. The students have no experience of using any educational games prior to this study. 
Results showed that most students are fascinated with the idea of using games for learning with all of them believing that learning with games can be fun, most of them believe games can help them to do better in their learning as well as can make learning more interesting. Also, games can offer learning opportunities in their learning process. Most students also found that they have the skills to use games. This is a good indicator that the students have the competencies of using the technology should university implement the technology in the future. It will also eliminate training cost and better leverage the skills already owned by the student. This is also probably because our samples are mostly IT student, thus they are quite competent in operating computer applications including online games.

Students also showed an encouraging attitude towards using games such as games can make subject more fun and they also choose to learn using online games if possible. In addition, students also vote in favor of using educational games. This study found some interesting information about our younger generation preferences in learning approach. This is a good indicator that our students are having preferences towards new technology for their learning. Hence, introducing new learning technology such as EG is appropriate with their preferences. Their knowledge of technology and competencies in using information systems should be leveraged by the government or university administration for better quality of education in higher education learning.

However, more studies are still needed to understand our student's preferences. Furthermore, our study used a limited number of samples; therefore the findings should be treated with caution. Other limitations are samples are only from one university, future study should have data collected from several universities including public and private universities. In this study, we only used 4 direct factors whereby there are also several other factors that have to be tested. Nevertheless, this study provide some interesting initiatives for further investigation regarding EG in higher education.

Hopefully, the findings from this study will shed some light on Malaysian higher education students' preferences towards using educational games in their learning. It should be useful for instructional game designers to assess students' opinions and for decision making process in implementing such technology in the future.

\section{REFERENCES}

1. Federation of American Scientists (FAS). Harnessing the power of video games for learning. 2006 [cited 8 May 2010].

2. $\quad$ Prensky, M., Digital Game-Based Learning. 2001, New York: Mc Graw Hill.

3. Gee, J.P., What video games have to teach us about learning and literacy. 2003, New York: Palgrave MacMillan.

4. Garris, R., R. Ahlers, and J.E. Driskell, Games, Motivation, and Learning: A Research and Practice Model. Simulation and Gaming, 2002. 33(4): p. 441-467.

5. Norizan, M.D., Pendekatan Bercerita dan Permainan dalam Pembangunan Perisian Kursus Akhlak Islamiah. 2003, UKM: Bangi.

6. Izam Shah, B., Perisian Pengembaraan Multimedia :Edutainment Dalam Pendidikan Agama Islam Sekolah Rendah, in Fakulti Teknologi dan Sains Maklumat. 2007, Universiti Kebangsaan Malaysia: Bangi, Malaysia.

7. Roslina Ibrahim, et al., Students Perceptions of Using Educational Games to Learn Introductory Programming. Computer and Information Science, 2011. 4(1): p. 205 - 216.

8. Barnes, T., et al. Game2Learn: Building CS1 Learning Games for Retention. in ITiCSE'07. 2007. Dundee, Scotland, United Kingdom.

9. Garzotto, F. Investigating the Educational Effectiveness of Multiplayer Online Games for Children. in Interaction Design and Children (IDC 2007). 2007. Aalborg, Denmark: ACM Press.

10. Virvao, M.K., George. Manos Konstantinos Combining software games with education: Evaluation of its educational effectiveness. Educational Technology \& Society, 2005. 8(2): p. 54-65.

11. Hill, J., Impacts of playing video games on learning in children, in Literature Synthesis for Applying Research, M.Y. Tollett, Editor. 2006, The University of Georgia, Athens: Georgia.

12. Sugimoto, M. What can children learn through game-based learning systems. in 1st IEEE International Workshop on Digital Game and Intellignet Toy Enhanced Learning (DIGITEL '07). 2007: IEEE Xplore. 


\section{Issues in Information Systems}

Volume XII, No. 1, pp. 120-133, 2011

13. Jaspaljeet, S.L.L.W., Mohana Shanmugam,Saraswathy Shamini Gunasekaran, Siva Kumar Dorairaj, Designing Computer Games to Introduce Programming to Children, in Information Technology and Multimedia at UNITEN (ICIMU’ 2008), Uniten, Editor. 2008: Selangor, Malaysia. p. 643-647.

14. Oblinger, D.G., Games and learning :Digital games have the potential to bring play back to the learning experience. Educause quarterly 2006(3): p. 5-7.

15. Rubijesmin, A.L. Understanding Malaysian students as gamers: Experience. in Proceedings of the 2nd International Conference on Digital interactive Media in Entertainment and Arts 2007. Perth, Australia: ACM.

16. Roslina, I., C.M.Y. Rasimah, and J. Azizah. Computer Games Playing Activities: Habits of Universiti Teknologi Malaysia Student. in International Conference on IT and Multimedia (ICIMU). 2008. Bangi, Selangor: Uniten.

17. Nor Azan, M. and S. Wong, Game Based Learning (GBL) Model for History Courseware: A Preliminary Analysis, in International Symposium on Information Technology (ITSIM). H.e.a. (Eds.), Editor. 2008, UKM: Kuala Lumpur, Malaysia. p. 253-260.

18. Zuhaira, M.Z., Pembangunan Perisian Permainan Multimedia untuk Sains Prasekolah: Dam Cuaca. 2007, UKM: Bangi.

19. Hanafizan, H., C.E. Zarina, and S. Hashim, A Conceptualized Framework for Edutainment., in Informing Science and IT Education Conference InSITE 2003 - Where Parallels Intersect. 2003, Information Science Institute: Pori, Poland. p. 1078-1083.

20. Zarina, C.E., Hanafizan Hussain, Theoretical Framework for Edutainment- The Cognitive Engineering, in 6th WSEAS International Conference on Multimedia, Internet \& Video Technologies. 2006: Lisbon, Portugal p. 18-22.

21. Roslina, I. and J. Azizah, Educational Games Design Framework: Combination of Game Design, Pedagogy and Content Modeling, in International Conference on Electrical Engineering and Informatics (ICEEI). 2009: UKM, Selangor, Malaysia. p. pp. 293-298.

22. Nor Azan, M., J. Azizah, and S. Wong, Digital Game-based learning (DGBL) model and development methodology for teaching history. WSEAS Transactions on Computers, 2009. 8(2): p. 322-333.

23. Noor Azli, M., M. Nor Azan, and C. Shamsul Bahri. Digital Games Based Learning. in International Symposium on Information Technology (ITSIM). 2008. Kuala Lumpur, Malaysia.

24. Roslina, I. and Y. Nazli, Development and effectiveness of educational games for learning introductory programming, in DPP Research Report. 2009, CTL Research Report, UTM, Malaysia: Skudai, Johor.

25. Kebritchi, M., Factors affecting teachers' adoption of educational computer games: A case study. British Journal of Educational Technology, 2010. 44(2): p. 256-270.

26. de-Freitas, S., Learning in immersive worlds: A review of game based learning, in JISC elearning progrmme. 2006, JISC: London.

27. Bourgonjon, J., et al., Students' perceptions about the use of video games in the classroom. Computers and Education, 2010. 54(2010): p. 1145-1156.

28. Vinod, S., B.-P. Karen, and P. Susan, Using video games to enhance learning in digital systems, in Proceedings of the 2008 Conference on Future Play: Research, Play, Share. 2008, ACM: Toronto, Ontario, Canada.

29. Amri, Y., A Conceptual Framework for Serious Games and its Validation, in School Of Electronics and Computer Science. 2010, Southampton: Southampton. p. 195.

30. Davis, F.D., Perceived usefulness, perceived ease of use, and user acceptance of information technology. MIS Quarterly, 1989. 13(Sep 1989): p. 319-340.

31. Venkatesh, V., et al., User acceptance of information technology: Toward a unified view. MIS Quarterly, 2003. 27(3): p. 423 - 478.

32. Hsu, C.-L. and H.-P. Lu, Why do people play on-line games? An extended TAM with social influences and flow experience. Information and Management, 2004. 41(2004): p. 853-868.

33. Ha, I., Y. Yoon, and M. Choi, Determinants of adoption of mobile games under mobile broadband wireless access environment. Information and Management, 2007. 44(2007): p. 276 - 286.

34. Marchewka, J.T., C. Liu, and K. Kostiwa, An Application of the UTAUT Model for Understanding Student Perceptions Using Course Management Software. Communications of the IIMA, 2007. 7(2): p. 93 - 104. 